\title{
THE MILLIPEDE GENUS PROPOLYDESMUS VERHOEFF, 1895 REDEFINED, WITH A REVISION OF THE GENUS IN THE CANARY ISLANDS (DIPLOPODA, POLYDESMIDA, POLYDESMIDAE)
}

\author{
H. Enghoff* and S. I. Golovatch**
}

\begin{abstract}
The genus Propolydesmus Verhoeff, 1895 is redefined, with Hormobrachium Attems, 1940 considered as its subjective junior synonym (syn. n.!); it currently encompasses at least a dozen valid species ranging from Macaronesia in the west to Central Europe in the east. Two species of Propolydesmus are known from the Canary Islands: P. laevidentatus (Loksa, 1967) (= Polydesmus brincki Demange, 1970, syn. n.!), comb. n. ex Polydesmus, occurring in Madeira, the Azores and Tenerife, Canary Islands, and P. dismilus (Berlese, 1891), comb. n. ex Polydesmus, which is newly recorded from Macaronesia (Canary Islands, Tenerife). Gonopods of both these species are illustrated, and the range of variation in P. laevidentatus is shown to be considerable.
\end{abstract}

Key words: Diplopoda, Polydesmidae, Propolydesmus, taxonomy, Canary Islands

\section{RESUMEN}

Redefinición del género Propolydesmus Verhoeff, 1895 y revisión del género en las islas Canarias (Diplopoda, Polydesmida, Polydesmidae)

Se redefine el género Propolydesmus Verhoeff, 1895 -considerando a Homobrachium Attems, 1940 como un sinónimo junior subjetivo (syn. n.) - el cual comprende una docena de especies extendidas desde Macaronesia, al oeste, hasta Centroeuropa, al este. En las islas Canarias se conocen dos especies de Propolydesmus: P. laevidentatus (Loksa, 1967) (= Polydesmus brincki Demange, 1970, syn. n.), comb. n. ex Polydesmus, que vive en Madeira, Azores y Tenerife, y P. dismilus (Berlese, 1891), comb. n. ex Polydesmus, que se cita por primera vez en Macaronesia (islas Canarias: Tenerife). Se ilustran los gonopodos de ambas especies y se demuestra el considerable grado de variación de $P$. laevidentatus.

Palabras clave: Diplopoda, Polydesmidae, Propolydesmus, taxonomía, Islas Canarias.

\section{Introduction}

Until very recently, Propolydesmus Verhoeff, 1895 was considered as one of the numerous subgenera of the prolific Palaearctic genus Polydesmus Latreille, 1802/03 (e.g. Attems, 1940). However, the cladistic analysis by Djursvoll et al. (2001) showed Propolydesmus to be cladistically distinct enough to warrant the rank of full genus. In the present paper, the circumscription of Propolydesmus is redefined by including Hormobrachium Attems, 1940, as a junior synonym.

* Zoological Museum, University of Copenhagen, Universitetsparken 15, DK-2100 Copenhagen Ø, Denmark. e-mail: henghoff@zmuc.ku.dk

** Institute for Problems of Ecology \& Evolution, Russian Academy of Sciences, Leninsky pr. 33, Moscow 117071 (V-71), Russia. email: sgol@orc.ru 
As regards Macaronesia, only Propolydesmus laevidentatus (Loksa, 1967) has heretofore been reported from the Canary Islands, whereas $P$. brinc$k i$ (Demange, 1970) was believed to be confined to Madeira and the Azores (Vicente \& Enghoff, 1999), and P. miguelinus (Attems, 1908) has been reported from the Azores (as well as from continental Portugal, Mauriès, 1964). In the Canaries, P. laevidentatus seems to occur in Tenerife only, being quite common and encountered both in epigean and subterranean habitats. Furthermore, several samples provisionally identified as $P$. cf. laevidentatus have only been reported from Tenerife as well (Vicente \& Enghoff, 1999).

In the present paper we revise the abundant samples of $P$. laevidentatus for outlining its range of variation, and we synonymize $P$. brincki under $P$. laevidentatus. A congener, P. dismilus (Berlese, 1881), is recorded for the first time from the Canary Islands and Macaronesia.

The material treated here has been shared between the collections of Zoologisk Museum, University of Copenhagen, Denmark (ZMUC); Departamento de Biología Animal (Zoología), Universidad de La Laguna, Tenerife, Spain (DZUL); Centro de Zoologia, Instituto de Investigação Científica Tropical, Lisbon, Portugal (CZIICT); Swedish Museum of Natural History, Stockholm, Sweden (SMNH); and Zoological Museum, State University of Moscow, Russia (ZMUM).

\section{Systematic part}

\section{Genus Propolydesmus Verhoeff, 1895}

Propolydesmus Verhoeff, 1895. Type species: Polydesmus pectiniger Verhoeff, 1893.

Hormobrachium Attems, 1940, syn. n. Type species: Polydesmus helveticus Verhoeff, 1894.

Notes: When promoting Propolydesmus to full genus, Djursvoll et al. (2001) considered in their analysis only two species: P. brincki (Demange, 1970) and P. miguelinus (Attems, 1908). The type species of Propolydesmus, Polydesmus pectiniger Verhoeff, 1893, was not examined.

Djursvoll et al. (2001) provided the following diagnosis of Propolydesmus:

«Presence of a strongly reduced (dorsoventrally compressed) "femorite". With neither accessory seminal chamber nor setose pulvillus at its orifice. Distal loop of seminal groove considerably long. "Distofemoral" process rather evident but thin and small.
Additional characteristics: Body size small $(<10$ $\mathrm{mm}), 20(18+1+\mathrm{T})$ body rings in male and female. Endomerite set off from "femorite" by a distinct cingulum, unipartite, strongly elongate and slightly curved, never subfalcate. Epigynal ridge rather simple. Vulva short to elongate».

However, such a diagnosis is somewhat deficient from the very start, as $P$. pectiniger is ca. $13.5 \mathrm{~mm}$ long (cf. Verhoeff, 1893; Attems, 1940) and at least $P$. laevidentatus has a distinct accessory seminal chamber as well as a pilose pulvillus, however small and delicate (Figs. 1, 2, 6, 7). As regards a longish distal loop of the seminal groove, we find it absolutely normal, Polydesmus-like, in all Propolydesmus species (Figs. 1-3), i.e. neither very long nor very short, apparently related to the quite usual degree of gonofemorite torsion. In addition, the very strong resemblance in gonopod conformation noted by Verhoeff (1896) between Propolydesmus pectiniger and Polydesmus germanicus Verhoeff, 1896, and by Schubart (1931) between Propolydesmus pectiniger, P. miguelinus, Polydesmus dismilus, P. heroldi Schubart, 1931 and the $P$. helveticus-group, has been ignored altogether. Instead, in contrast to Attems (1940) who placed P. germanicus, P. dismilus, $P$. heroldi, P. helveticus Verhoeff, 1894 and several other species in the subgenus Hormobra-chium Attems, 1940 (thus providing a genus-group name for the helveticus-group) and, following Schubart (1931), treated Hormobrachium as probably closest to Propolydesmus, Djursvoll et al. (2001) preferred to consider Hormobrachium as a strict synonym of Polydesmus s. str.

The main "trademarks" of Propolydesmus thus remain the particularly short, stout "femorite", the prominent cingulum/sulcus demarcating the exomerite from the "femorite", the slightly curved and unipartite exomerite, and the small but evident "distofemoral" process. Following Attems (1940), the absence of a solenomere in Propolydesmus is also noteworthy, virtually the only serious distinction he made viz-a-viz Hormobrachium. (In Polydesmus (Hormobrachium) mistrei Brölemann, 1902 there is apparently no pulvillus, which agrees with the definition of Propolydesmus by Djursvoll et al. (1999), but this character has now lost significance since our scanning electron microscope studies (Figs. 6-7) have demonstrated a pulvillus in Propolydesmus laevidentatus).

Propolydesmus sensu Djursvoll et al. is one of the westernmost species groups among the Palaearctic Polydesmus sensu lato. Features, most likely apomorphies, that allow to distinguish this species group are: the relatively small body - the particularly 


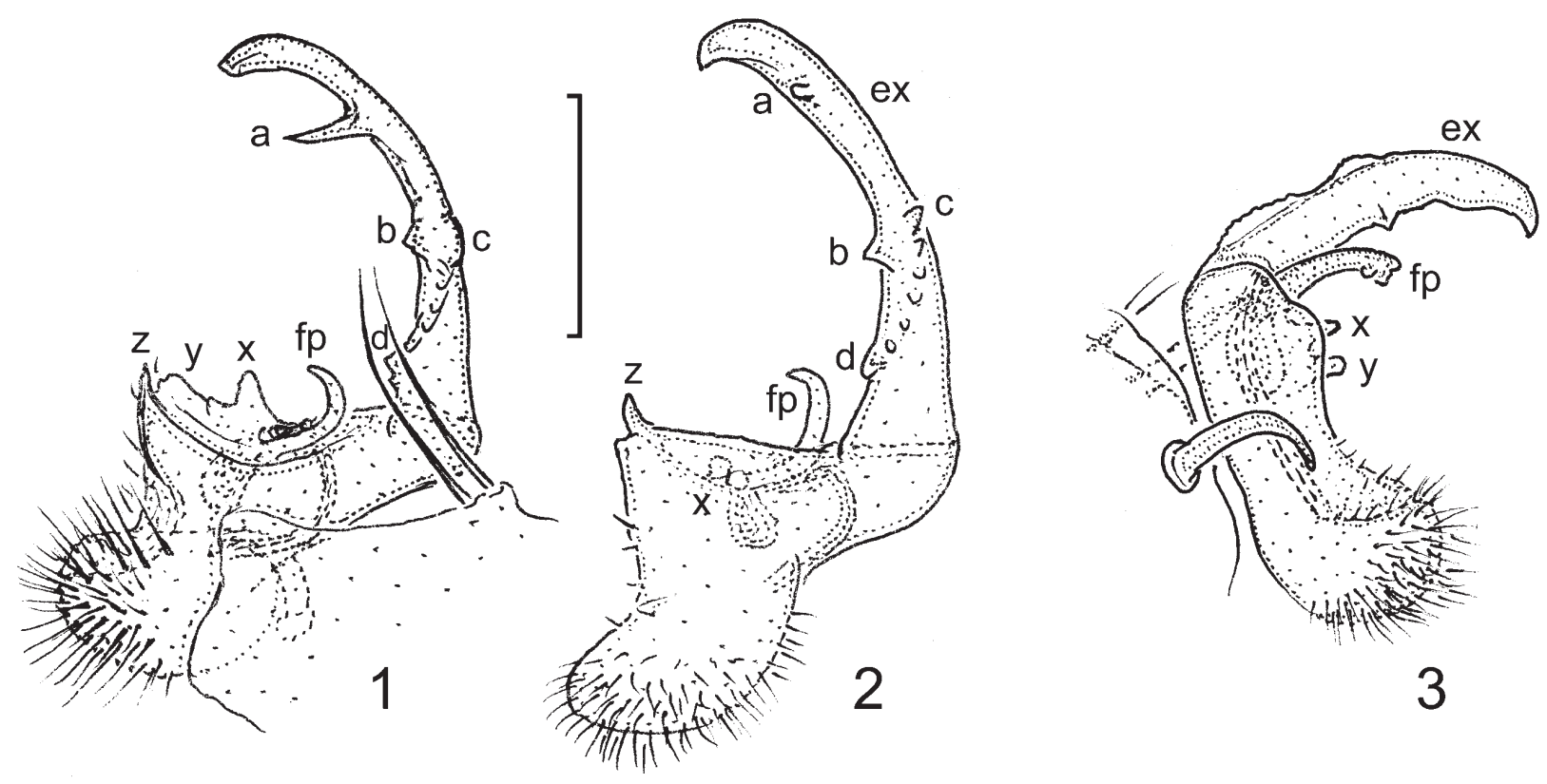

Figs. 1-2.- Gonopods of Propolydesmus laevidentatus (Loksa, 1967). - 1, Tenerife, Barranco de San Antonio, lateral view. - 2, Monte del Agua, Los Silos, lateral view.

Fig. 3.- Gonopods of $P$. dismilus (Berlese, 1891). - 3, Tenerife, Cueva de las Mechas, mesal view. - Scale bar $0.2 \mathrm{~mm}(1,2), 0.4$ $\mathrm{mm}$ (3). - ex: exomerite; a, b, c, d: teeth/protuberances on exomerite; fp: distofemoral process (= acropodite); $\mathrm{x}, \mathrm{y}, \mathrm{z}$ : protuberances on femorite.

Figs. 1-2.- Gonopodos de Propolydesmus laevidentatus (Loksa, 1967). - 1, Tenerife, Barranco de San Antonio, vista lateral. 2, Monte del Agua, Los Silos, vista lateral.

Fig. 3.- Gonopodos de P. dismilus (Berlese, 1891). - 3, Tenerife, Cueva de las Mechas, vista mesal. - Escalas: $0.2 \mathrm{~mm}(1,2), 0.4$ $\mathrm{mm}$ (3). - ex: exomerito; a, b, c, d: diente/protuberancias del exomerito; fp: proceso distofemoral (= acropodito); x, y, z: protuberancias del femorito.

robust gonopod femorite - the 2-3 characteristic teeth/protuberances (x, y and $\mathbf{z}$, cf. Demange, 1970) on the femorite caudally of the accessory seminal chamber - the small but evident, always subfalcate "distofemoral" process (= acropodite) at the accessory seminal chamber - the long, armed, slightly curved exomerite set off from the femorite by a very distinct sulcus mesally. Geographically the group is also quite coherent: $P$. pectiniger is known from near Coimbra, mainland Portugal, P. miguelinus occurs both in mainland Portugal and the Azores, and P. laevidentatus $(=P$. brincki) in the Canary Islands, the Azores, and Madeira.

In the anatomically and geographically close Polydesmus heroldi (Sevilla, Spain) and P. dismilus (Canary Islands, mainland Italy, Spain and Algeria) the body is larger (closer to $2 \mathrm{~cm}$ ). However, the gonopod is virtually of the same conformation as in Propolydesmus sensu Djursvoll et al., although the femorite is slightly more elongate (= less robust).
Even the characteristic 2-3 protuberances (at least $\mathbf{x}$ and $\mathbf{y}$ ) lying caudally of the pulvillus are the same, apparently homologous, while the "distofemoral" process (fp) is either also rather small ( $P$. heroldi) or somewhat larger $(P$. dismilus $)$. $P$. germanicus (Western Alps up to central Germany in the north) shows the same basic features as $P$. herold $i$ and $P$. dismilus but at most 1-2 protuberances caudally of the pulvillus plus a somewhat longer base of the exomerite in relation to the sulcus (cf. Verhoeff, 1896; Attems, 1940; Tadler \& Thaler, 1993) while the smaller $P$. mistrei (France) apparently lacks a pulvillus and has only a single but more prominent, dentiform protuberance near the orifice of a welldeveloped accessory seminal chamber. In general, reduction of either the pulvillus or even both the pulvillus and the accessory seminal chamber along with body miniaturization is a regressive trend common to occur in Polydesmidae (cf. Verhoeff, 1895; Attems, 1940). In the remaining, largely also 
Alpine Hormobrachium in the sense of Attems (1940), i.e. P. helveticus Verhoeff, 1894 (the type species), P. corsicus Schubart, 1931, P. troglobius Latzel, 1889, P. racovitzai Brölemann, 1910, and P. testaceus (C.L. Koch, 1847), the orifice of both the accessory seminal chamber and the seminal groove is placed on a more or less distinct, often hypertrophied solenomere, the "distofemoral" process is more or less reduced, the gap between the femorite and the exomerite grows while the exomerite often becomes falcate. Apparently, these developments are apomorphies perhaps even correlated with one another. As regards the degree of development of a solenomere, this is certainly only a species-specific trait in Polydesmus s.l., hardly more than that.

In other words, the evolution and classification of Polydesmus sensu lato deserve a more profound analysis, the results obtained by Djursvoll et al. (2001) being only to be understood as highly provisional. The situation concerning Propolydesmus clearly demonstrates not only the above statement but also allows for a slightly refined diagnosis and a different classification to be proposed. (A potentially major problem with the analysis of Djursvoll et al. (1999) is that they only considered Polydesmus sensu Hoffman (1980) without addressing the question of whether this is a monophyletic group. Several "satellite" genera were thus not included in the analysis. This is true, e.g., of Serradium Verhoeff, 1941, the type species of which was shown by Enghoff et al. (1997) to be very similar in gonopod configuration to species of the subgenus Acanthotarsius Attems, 1940, which Djursvoll et al regarded as a synonym of Polydesmus, although they did recognise this problem.)

For the time being, we regard Propolydesmus as a valid genus that encompasses over a dozen West to Central European and/or West Mediterranean species.

Diagnosis: Small to medium-sized Polydesmuslike species with $20(18+1+\mathrm{T})$ body segments in male and female, a relatively to very short/stout gonopod "femorite" largely crowned by a more or less distinct, usually small to moderate, often subfalcate but never hypertrophied "distofemoral" process, with or without a solenomere. Accessory seminal chamber largely if not always discernible, but a pilose pulvillus sometimes apparently absent. Often 2-3 characteristic protuberances caudally of orifice of both seminal groove and accessory seminal chamber, this orifice always placed at base of a unipartite "distofemoral" process. Exomerite strongly developed, unipartite, gently curved to subfalcate, armed, normally set off from femorite by a distinct sulcus/cingulum at least medially, especially prominent when a solenomere is developed and the "distofemoral" process is more strongly reduced. Epigynal ridge usually if not always rather simple, inconspicuous. Vulvae short to elongate.

Distribution: From Macaronesia in the west to Central Europe in the east.

SPECIES INCLUDED (more or less from west to east): P. laevidentatus (Loksa, 1967) comb. n. (= Polydesmus brincki Demange, 1970) (Azores, Canary Islands and Madeira); P. miguelinus (Attems, 1908) (Azores and mainland Portugal); $P$. pectiniger (Verhoeff, 1893) (mainland Portugal); $P$. dismilus (Berlese, 1891) comb. n. (= Polydesmus bolivari Verhoeff, 1907) (Canary Islands, mainland Spain, Balearic Islands, Italy and Algeria); P. heroldi (Schubart, 1931) comb. n. (mainland Spain); $P$. haroi (Mauriès \& Vicente, 1977) comb. n. (mainland Spain), P. mauriesi (Vicente, 1979) comb. n. (mainland Spain), P. plicatus (Ceuca, 1962) comb. n. (France), P. mistrei (Brölemann, 1902) comb. n. (France); P. racovitzai (Brölemann, 1910) comb. n. (France, mainland Spain); P. corsicus (Schubart, 1931) comb. n. (Corsica); P. testaceus (C.L. Koch, 1847) comb. n. (= Polydesmus subinteger Latzel, 1884) $=$ Polydesmus harpagonifer $($ Verhoeff, 1930)) (W and C. Europe); P. germanicus (Verhoeff, 1896) comb. n. (Belgium, France, Switzerland, southern Germany, Hungary); P. helveticus (Verhoeff, 1894) comb. n. (France, Switzerland, Austria, southern Germany); and P. troglobius (Latzel, 1889) comb. n. (France, northern Italy).

\section{Propolydesmus in the Canary Islands}

The two Canarian species of Propolydesmus are easily recognisable by their gonopods (Figs. 1-3). They differ considerably in size: P. laevidentatus is small (7-8 mm long) and pale, whereas $P$. dismilus is quite large (15-24 $\mathrm{mm}$ long) and generally red- to yellow-brown.

Propolydesmus laevidentatus (Loksa, 1967), comb. n. Polydesmus miguelinus laevidentatus Loksa, 1967: 133. Polydesmus brincki Demange, 1970: 25, syn. n.

Polydesmus brincki var. longispinosa Demange, 1970: 26, syn. n. Polydesmus laevidentatus - Vicente \& Enghoff, 1999: 189. Polydesmus cf. laevidentatus - Vicente \& Enghoff, 1999: 190. Propolydesmus brincki - Djursvoll et al., 2000: 56.

MATERIAL STUDIED: CANARY ISLANDS, TENERIFE: $10,1 Y$ (ZMUC), 10 , 1Y (ZMUM), Galería de Belén, 13.vi.1999. - 

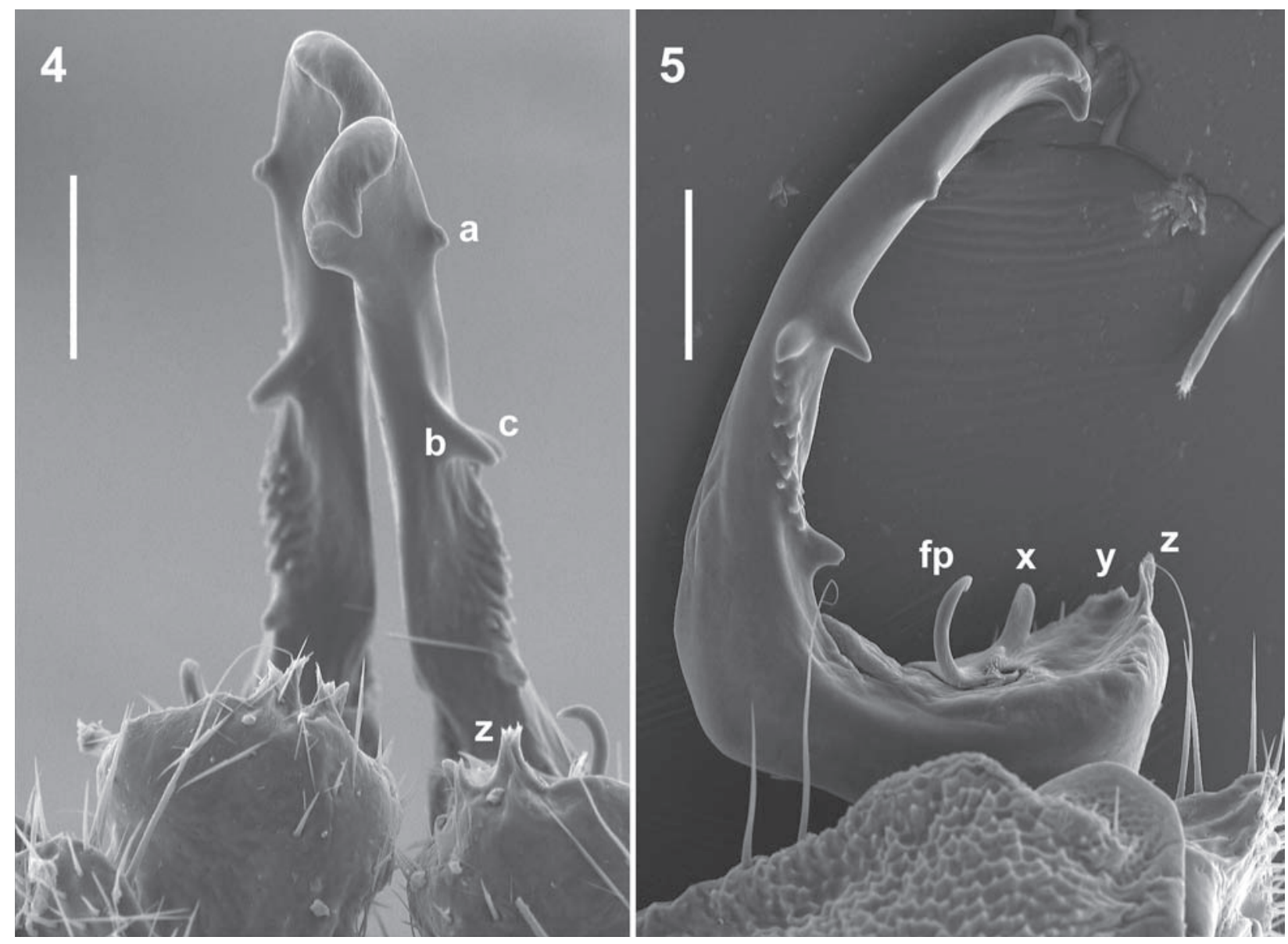

Figs. 4-5.— Gonopods of Propolydesmus laevidentatus ("brincki-type", specimens from Madeira. - 4. both gonopods, ventro-caudal view. -5 . right gonopod, lateral view. - Scale bars $0.1 \mathrm{~mm}$. - fp: "distofemoral” process (= acropodite); a, b, c: teeth/protuberances on exomerite; $x, y \& z$ : protuberances on "femorite".

Figs. 4-5.- Gonopodos de Propolydesmus laevidentatus ("brincki-type", ejemplares de Madeira. - 4. ambos gonopodos, vista ventro-caudal. - 5. gonopodo derecho, vista lateral. - Escala: $0.1 \mathrm{~mm}$. - fp: proceso "distofemoral" (= acropodito); a, b, c: dientes/protuberancias del exomerito; x, y \& z: protuberancias del "femorito".

10 (ZMUM), same locality, 5.vi.1999. - $20 \quad 0$ (ZMUC), same locality, 6.vi.1999. - 10 (DZUL), Cueva de Breveritas, 18.xii.1999. - 10,1 juv. (DZUL), Cueva de Felipe Reventón, 9.iii.2000. - 60 0, 3Y Y (DZUL), Cueva del Sobrado SVP, 22.v.1999; all leg. GIET. - 10 (SMNH), Barranco de San Antonio, 8.iv.1957; leg. O. Lundblad. - 10 , 8Y Y (CZIICT), Monte del Agua, Los Silos, 26.vi. 1954. - leg. J. Mateu. - 200 (ZMUC), Teno, Foresta de los Silos, 25.iii.1984, leg. A. Vigna. 10 (ZMUC), same locality, $850 \mathrm{~m}, 15$. iii.1984, leg. E. Colonelli. - 10, 2Y Y (ZMUC), same locality, 850-950 m, 15.iii.1984, leg. G. Carpaneto.

MADEIRA: numerous samples (ZMUC).

First described as a subspecies of the Portuguese-Azorean Polydesmus miguelinus Attems, 1908, laevidentatus was recorded by Loksa
(1967) from Tenerife. A few years later, Demange (1970), apparently unaware of Loksa's paper, described Polydesmus brincki, as well as a var. longispinosa from Madeira and the Azores. Vicente \& Enghoff (1999) considered laevidentatus to be much closer to brincki than to miguelinus, elevated laevidentatus to specific rank, and recorded it from several localities in Tenerife, including caves. Some of the samples listed above were already studied by Vicente \& Enghoff (1999) and referred by these authors to either laevidentatus or cf. laevidentatus.

A direct, side-by-side comparison of the above abundant material with the no less abundant samples of brincki from Madeira and the Azores 

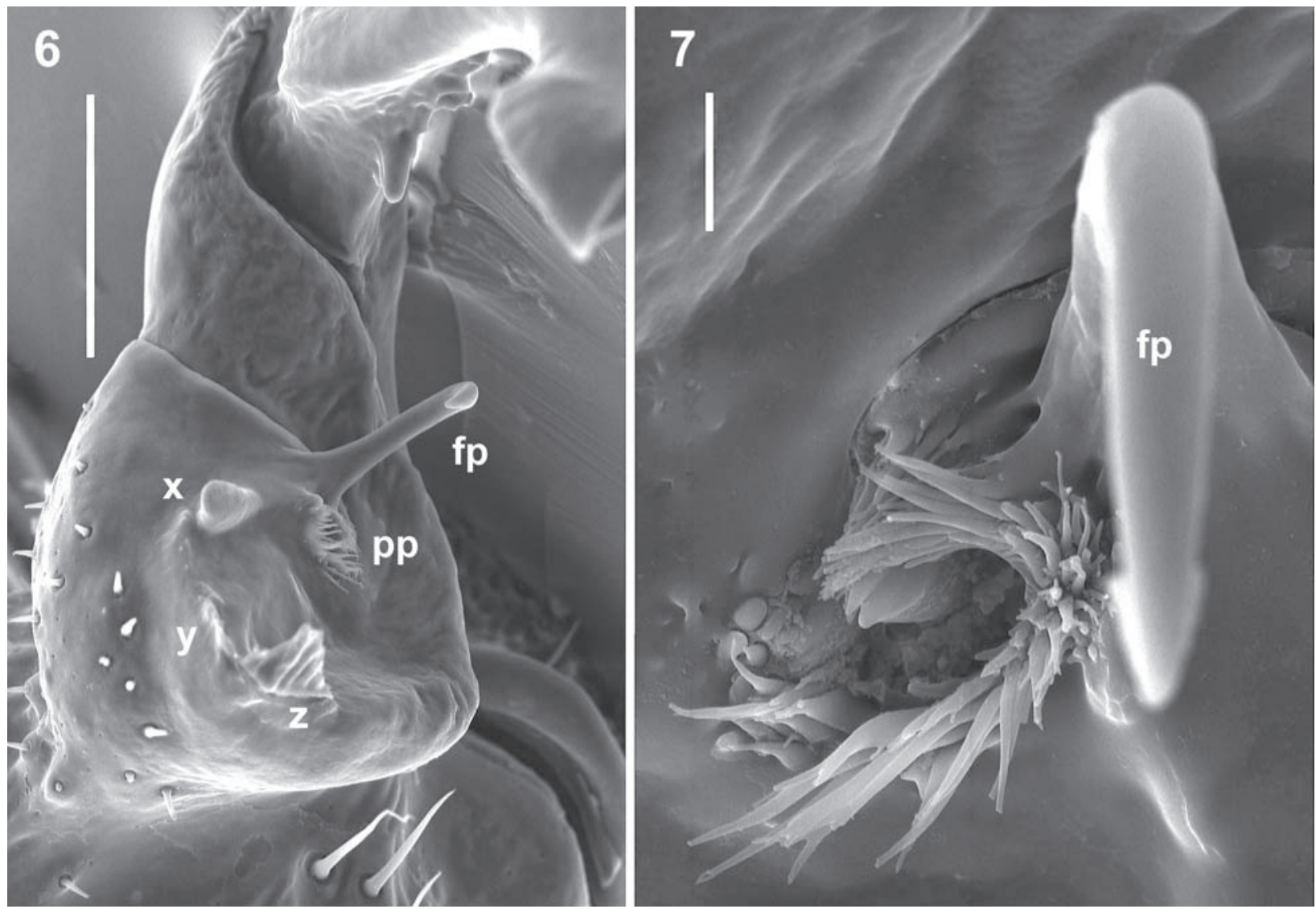

Figs 6-7.- Gonopods of Propolydesmus laevidentatus ("brincki-type", specimen from Madeira. - 6. femorite. - 7. do., close-up of pilose pulvillus. - Scale bars $0.1 \mathrm{~mm}(6), 0,01 \mathrm{~mm}$ (7). - fp: "distofemoral" process (= acropodite); pp: pilose pulvillus; x, y \& z: protuberances on "femorite".

Figs 6-7.- Gonopodos de Propolydesmus laevidentatus ("brincki-type", ejemplar de Madeira. - 6. femorito. - 7., femorito: detalle del pulvilo piloso. - Escalas: $0.1 \mathrm{~mm}(6), 0,01 \mathrm{~mm}(7)$. - fp: proceso "distofemoral” (= acropodito); pp: pulvilo piloso pulvillus; x, y \& z: protuberancias del "femorito".

(ZMUC Collection) has revealed that we actually face a single but quite variable species, P. laevidentatus by priority. Indeed, the gonopod in this species shows pronounced variation in the degree of development of the exomerital teeth a to $\mathbf{d}$ in terms of Demange (1970) (Figs. $1 \& 2$ ). Tooth a can vary from very short, nearly rudimentary, rather characteristic of most of the samples hitherto referred to brincki (Fig. 2), to very long, dagger-shaped as is the case in most of the samples hitherto referred to laevidentatus (Fig. 1). Already Demange (1970) noted this variation, and he even described a variety, $P$. brincki var. longispinosa, to emphasize the dagger-shaped condition of tooth a in some specimens, but he never compared brincki with lae- videntatus. In some samples from the Azores, one and the same male can have a longer tooth $\mathbf{a}$ in one of the gonopods but a much shorter a in the other. Similarly, the gonopods of the abovelisted male from Monte del Agua prove to be like those of a quite typical brincki (Fig. 2) while some further syntopic males appear like typical laevidentatus (cf. Vicente \& Enghoff, 1999). Tooth a is often broken off at the base, but this condition is easy enough to trace due to a subtruncate remainder. Teeth $\mathbf{b}$ and $\mathbf{d}$ are likewise somewhat variable in shape, just like protuberances $\mathbf{x}, \mathbf{y}$ and $\mathbf{z}$ on the femorite (Figs. $1 \& 2$ ), but always relatively short. Tooth c (Fig. 2) claimed characteristic of brincki (cf. Demange, 1970) can actually be strongly redu- 
ced and barely traceable (Fig. 1). Hardly surprisingly, Loksa (1967) failed to notice even a minor swelling in place of tooth $\mathbf{c}$ in his Teneriffan samples of laevidentatus. The row of folds/denticles between teeth $\mathbf{c}$ and $\mathbf{d}$ can also vary from wellexpressed (Figs. $1 \& 2$ ), this being more characteristic of typical laevidentatus, to barely discernible. Not surprisingly, Demange (1970) noticed no such row in his brincki.

In other words, the above variation in gonopod exomerital armature proves to be purely individual, not even microgeographical. The same can be said about any of the peripheral characters studied (coloration, outlines of paraterga and epigyne, metatergal sculpture and setae, etc.), which, too, prove slightly variable but always showing all possible intergradations in sufficiently abundant samples. It is this relatively pronounced variation that accounts for Vicente \& Enghoff's (1999) failure to unequivocally attribute some Teneriffan Propolydesmus samples to laevidentatus.

So we do not hesitate to advance the following new formal synonymy: Polydesmus laevidentatus Loksa, $1967=$ Polydesmus brincki Demange, 1970 , syn. $\mathbf{n}$.

The presence or absence of a pilose pulvillus supporting the orifice of an accessory seminal chamber and/or seminal groove is sometimes difficult to be certain about as this structure is often too tiny and delicate to be readily observed, especially in smaller species. Neither Loksa (1967) nor Demange (1970) mentioned a pulvillus in their descriptions of laevidentatus and brincki, respectively. Scanning electron microscopy, however, easily reveals a small, yet distinct pulvillus in laevidentatus (Figs. 6-7), see further below.

Propolydesmus laevidentatus is currently known from Madeira, the Azores (Flores, Faial, Pico and Terceira) (Demange, 1970), and the Canary Islands (Tenerife only). It thus joins the small group of millipede species classified as "Macaronesian endemics" by Vicente \& Enghoff (1999), viz., Macroxenus enghoffi Nguyen Duy-Jacquemin, 1996 (Canary and Cape Verde Islands), Hirudicryptus canariensis (Loksa, 1967) (Madeira and Canary Islands), Cynedesmus formicola (Cook, 1895) (Madeira and Canary Islands), and Cylindroiulus madeirae Attems, 1935 (Madeira and Azores, cf. Enghoff, 1992a).

Propolydesmus dismilus (Berlese, 1891), comb. n. Polydesmus dismilus Berlese, 1891: 59, 9.

Material studied: 10 (DZUL), Canary Islands, Tenerife, Cueva de las Mechas, 7.v.1999, leg. GIET.
This is the first record of this species in the Canary Islands as well as in entire Macaronesia. $P$. dismilus has hitherto been known from Italy (near Florence), mainland Spain (Valencia and largely caves in Granada and Huesca provinces), and Algeria (Attems, 1940; Vicente, 1981). The gonopod of the single Canarian specimen is shown in Fig. 3. One may notice that the "distofemoral" process (fp) is not a solenomere, as stated erroneously by Attems (1940), and that there are both a quite well-developed accessory seminal chamber and a pilose pulvillus at the base of fp. Moreover, there are two characteristic protuberances ( $\mathbf{x}$ and $\mathbf{y}$ ) just caudally of the pulvillus.

Our gonopod illustration (Fig. 3) matches that of Berlese (1891) much closer than that of Attems (1940), even though Attems claimed to have copied his from Berlese's work.

Propolydesmus dismilus is apparently an introduction from the adjacent mainland Europe or Africa. Troglophily of $P$. dismilus in Tenerife is nothing special, because it has long been known from several caves in Spain. A parallel case is constituted by the julid millipede Dolichoiulus typhlops Ceuca, 1973, which was originally described from a cave in continental Spain, subsequently discovered in several epigean sites in Spain (Enghoff 1992b) and recently discovered in caves in the Canary Islands (El Hierro and La Palma) (Enghoff, 2002).

\section{ACKNOWLEDGMENTS}

We are greatly obliged to Pedro Oromí (Tenerife, Spain), Rafael Rodríguez (Gran Canaria, Spain), Luis Mendes (Lisbon, Portugal) and Torbjörn Kronestedt (Stockholm, Sweden) who have provided the bulk of the material offered for study. The second author is most grateful to the Danish National Research Council for the financial support rendered, among other things, to accomplish the present project. We thank Søren Langemark and Birgitte Rubæk (ZMUC) for technical assistance.

\section{References}

Attems, C., 1940. Myriopoda 3. Polydesmoidea III. Fam. Polydesmidae, Vanhoeffeniidae, Cryptodesmidae, Oniscodesmidae, Sphaerotrichopidae, Peridontodesmidae, Rhachidesmidae, Macellolophidae, Pandirodesmidae. Das Tierreich, 70: i-xxxii + 1-577.

Berlese, A., 1891. Acari, Myriopoda et Scorpiones hucusque in Italia reperta, Polydesmus dismilus Berl. n. sp., 59, 9 .

Demange, J.-M., 1970. Myriapodes Diplopodes de Madère et des Açores. Boletim do Museu municipal do Funchal, 25: 5-43. 
Djursvoll, P., Golovatch, S. I., Johanson, K. A. \& MeIDELL, B., 2001. Phylogenetic relationships within Polydesmus sensu lato (Diplopoda: Polydesmidae). In: J. Wytwer \& S. I. Golovatch (eds.), Progress in Studies on Myriapoda and Onychophora. Fragmenta faunistica, 43(Supplement): 37-59.

EnghofF, H., 1992a. Macaronesian millipedes (Diplopoda) with emphasis on endemic species swarms on Madeira and the Canary Islands. Biological Journal of the Linnean Society, 46: 153-161.

Enghoff, H., 1992b. Dolichoiulus - a mostly Macaronesian multitude of millipedes. With the description of a related new genus from Tenerife, Canary Islands (Diplopoda, Julida, Julidae). Entomologica scandinavica Supplement, 40: 1-158.

Enghoff, H., 2002. Dolichoiulus typhlops Ceuca, 1973, in Canarian caves (Diplopoda, Julida, Julidae). Vieraea, 30: 147-152.

Enghoff, H., Caoduro, G., Adis, J. \& Messner, B., 1997. A new, cavernicolous, semiaquatic species of Serradium (Diplopoda: Polydesmidae) and its terrestrial, sympatric congener. With notes on the genus Serradium. Zoologica Scripta, 26: 279-290.

LOKSA, I., 1967. Diplopoden aus den Sammlungen von Prof. Dr. H. Franz auf den Kanarischen Inseln. Opuscula Zoologica Budapest, 7(1): 133-145.

MAuriÈs, J.-P., 1964. Sur quelques Diplopodes de la Péninsule ibérique. Bulletin de la Société d'Histoire naturelle de Toulouse, 99: 157-170.

SchubART, O., 1931. Einige neue Diplopoden von der Insel Korsika and aus Spanien. (Über Diplopoden $\mathrm{Nr}$. 18). Zoologischer Anzeiger, 94: 2-12.
TAdler, A. \& Thaler, K., 1993. Genitalmorphologie, Taxonomie und geographische Verbreitung ostalpiner Polydesmida (Diplopoda: Helminthomorpha). Zoologische Jahrbücher, Abteilung für Systematik, Ökologie und Geographie der Tiere, 120: 71-128.

Verhoeff, K. W., 1893. Neue Diplopoden der portugiesischen Fauna. Zoologischer Anzeiger, 16: 156-159, 161-169.

VerhoefF, K. W., 1895. Aphorismen zur Biologie, Morphologie, Gattungs- und Art-Systematik der Diplopoden. Zoologischer Anzeiger, 18: 203-211, 213-226, 237-244.

Verhoeff, K. W., 1896. Über Polydesmus germanicus n. sp. und Subg. Propolydesmus Verh. Zoologischer Anzeiger, 19: 313-317.

Vicente, M. C., 1981. Diplópodos epigeos de Cataluña, 1 (Gloméridos, Craspedosómidos y Polidésmidos). Eos, 57: 279-315.

Vicente, M. C. \& Enghoff, H., 1999. The millipedes of the Canary Islands (Myriapoda: Diplopoda). Vieraea, 27: 183-204. 